\title{
THROMBOLYSIS OF THROMBOSED ST. JUDE MEDICAL PROSTHETIC VALVES: RETHROMBOSIS-A SIGN OF TISSUE INGROWTH
}

\author{
M. J. Munclinger, MD, J. J. Patel, FCP, and A. S. Mitha, FRCP, KwaZulu/Natal, South Africa
}

Prosthetic valve thrombosis is one of the most frequent complications after valve replacement surgery. A second surgical procedure with debridement or replacement of the valve (or both) has been the traditional method of management, ${ }^{1}$ with systemic thrombolysis lingering as an alternative for more than two decades. ${ }^{2}$ The mortality with second valve replacement has been relatively high $(20 \%) .{ }^{3}$ With systemic thrombolysis the mortality is lower $(0 \% \text { to } 10 \%)^{2,4,5}$ but is associated with embolic complications that are usually without permanent sequelae. Rethrombosis occurs in $20 \%$ of patients after successful thrombolysis. ${ }^{5}$ A repeat thrombolysis has been advocated for patients with rethrombosis. ${ }^{5}$

Results of systemic thrombolysis in 10 patients receiving tissue plasminogen activator (TPA) for thrombosis of a left-sided St. Jude Medical valve (St. Jude Medical, Inc., St. Paul, Minn.) are presented here with a focus on the mid-term follow-up and the management of rethrombosis.

The clinical data and the follow-up of 10 consecutive patients are summarized in Table I. The international normalized ratio on admission was within the therapeutic range in only three of the 10 patients. The diagnosis was established and the treatment was monitored by cinefluoroscopy. TPA was administered as a bolus of $10 \mathrm{mg}$ followed by an infusion of $5 \mathrm{mg} / \mathrm{hr}$. When full valve mobility was achieved, TPA was stopped and a continuous infusion of heparin was commenced. At the same time warfarin was introduced, and when the therapeutic range of anticoagulation was achieved heparin was discontinued.

Successful thrombolysis was achieved in nine of 10 patients (Table II). A total dose of $100 \mathrm{mg}$ of TPA established satisfactory thrombolysis in 11 of the 13 treatments given.

In two patients complications developed that could be attributed to the administration of TPA. One patient had pelvic bleeding related to a recent gynecologic infection and was successfully treated medically. The second patient had an episode of epistaxis.

From the Department of Cardiology, University of Natal/Wentworth Hospital, Durban, KwaZulu/Natal, South Africa.

Published data were partly presented at Nineteenth Biennial Congress of Southern African Cardiac Society, Cape Town, Nov. 27-30, 1994.

Received for publication July 18, 1997; accepted for publication August 18, 1997.

Address for reprints: M. J. Munclinger, MD, Cardiac Unit, Wentworth Hospital, Private Bag Jacobs, Durban 4026, KwaZulu/Natal, South Africa.

J Thorac Cardiovasc Surg 1998;115:248-9

Copyright (c) 1998 by Mosby, Inc.

$0022-5223 / 98 \$ 5.00+0 \quad \mathbf{1 2} / \mathbf{5 4} / \mathbf{8 5 5 2 9}$
During follow-up, one patient who had successful thrombolysis died in a peripheral hospital with clinical signs of rethrombosis 2 weeks after discharge. He had not received therapeutic levels of anticoagulants. Three patients were found to have poor valve mobility, and a second course of TPA was administered. The second thrombolysis resulted in good valve mobility. All three patients with a second course of TPA returned with evidence of valve dysfunction as documented by limited leaflet mobility. Two of them were subjected to surgery, and evidence of tissue ingrowth involving the hinge points of the valves was found, similar to that in the patient who was operated on after an unsuccessful first course of thrombolysis.

Comparative data concerning the choice of thrombolytic agents are not available. We believe that the present group of 10 patients treated with TPA is the largest reported yet for this agent. The comparison of our results with those of Vitale and coworkers ${ }^{4}$ suggests that the method of administration (a long-term infusion versus an accelerated administration) is probably not significant. Rethrombosis was more prevalent in our patients than in those from other reports. ${ }^{2,4,5}$ Of the five patients with a rethrombosis and/or unsuccessful thrombolysis, one died in a peripheral hospital as a result of inadequate anticoagulation and three others were subjected to a second valve replacement. Evidence of tissue ingrowth in these three patients raises the question of whether surgical treatment, without a second course of thrombolytic agents, should be pursued immediately in patients having rethrombosis or valve dysfunction after a successful thrombolytic treatment. To this end, a retrospective blind reassessment of valve mobility in our patients was conducted and failed to demonstrate differences between patients in whom the tissue ingrowth was an important factor. We believe that tissue ingrowth was the cause of rethrombosis and not a failure of primary thrombolysis.

The results of reoperation and systemic thrombolysis are probably comparable, ${ }^{1-5}$ although no randomized study has compared them. Vitale and associates ${ }^{4}$ used thrombolysis in eight patients with a short duration of symptoms and with preserved movement of a disc or leaflet and found a very good mid-term results. Another group of 20 patients was submitted to an emergency reoperation, and tissue ingrowth was found in $65 \%$ of them; that is, another seven patients could have profited from thrombolysis. ${ }^{4}$ The definition of reliable echocardiographic criteria of the type of thrombosis (i.e., thrombus only or an apposition of thrombus on preexisting tissue ingrowth) by transthoracic or transesophageal echocardiography is necessary to allow an appropriate selection of patients for either method.

Systemic thrombolysis is an additive rather than a 
Table I. Clinical data of patients

\begin{tabular}{|c|c|c|c|c|c|c|}
\hline $\begin{array}{l}\text { Patient } \\
\text { No. }\end{array}$ & $\begin{array}{l}\text { Age } \\
(y r)\end{array}$ & $\operatorname{Sex}$ & $\begin{array}{c}\text { Months from } \\
\text { operation }\end{array}$ & Symptoms & Valve affected & $\begin{array}{c}\text { History of poor } \\
\text { compliance }\end{array}$ \\
\hline \multicolumn{7}{|c|}{ Patients with good long-term result } \\
\hline 1 & 13 & Male & $3 \dagger$ & Asymptomatic $\ddagger$ & MVR & Poor compliance \\
\hline 2 & 43 & Female & 4 & Asymptomatic $\ddagger$ & MVR & Warfarin defaulted \\
\hline $3^{*}$ & 22 & Female & 103 & Asymptomatic $\ddagger$ & AVR & Warfarin defaulted \\
\hline 4 & 50 & Male & 13 & Chest pain & MVR & No \\
\hline 5 & 16 & Male & 35 & Pyrexia§ & MVR & No \\
\hline \multicolumn{7}{|c|}{ Patients without satisfactory long-term results } \\
\hline 6 & 11 & Male & 29 & Dyspnea & AVR, MVR & Poor compliance \\
\hline $7^{*}$ & 39 & Female & 29 & Dyspnea, weakness & AVR, MVR & Warfarin defaulted \\
\hline 8 & 45 & Male & 75 & TIA & MVR & No \\
\hline 9 & 16 & Female & 8 & Dyspnea & MVR & No \\
\hline 10 & 13 & Male & 48 & $\mathrm{CCF}$ & MVR & Warfarin defaulted \\
\hline
\end{tabular}

$M V R$, Mitral valve replacement; $A V R$, aortic valve replacement; $T I A$, repeat transient cerebrovascular accidents documented as infarctions on computed tomographic scan; $C C F$, congestive cardiac failure lasting for a few months before presentation.

*Patient was pregnant at the time of dysfunction.

$\dagger$ Patient underwent two previous reoperations for thrombosed mitral valve.

$\ddagger$ Clinical suspicion was based on a new murmur.

$\S$ Corynebacterium sepsis.

Table II. Follow-up of patients

\begin{tabular}{|c|c|c|c|c|c|}
\hline $\begin{array}{l}\text { Patient } \\
\text { No. }\end{array}$ & $\begin{array}{l}\text { Follow-up } \\
\quad(\text { mo })\end{array}$ & $\begin{array}{c}\text { Repeat } \\
\text { thrombolysis } \\
\text { (mo) }\end{array}$ & $\begin{array}{l}\text { Operation } \\
\text { (mo from first } \\
\text { thrombolysis) }\end{array}$ & $\begin{array}{l}\text { Findings during } \\
\text { operation }\end{array}$ & Final result \\
\hline \multicolumn{6}{|c|}{ Patients with good long-term result } \\
\hline 1 & 36 & No & No & - & Asymptomatic; normal leaflets mobility \\
\hline 2 & 28 & No & No & - & Asymptomatic; normal leaflets mobility \\
\hline 3 & 24 & No & No & - & $\begin{array}{l}\text { Asymptomatic; normal leaflets mobility; } \\
\text { repeat pregnancy }\end{array}$ \\
\hline 4 & 20 & No & No & - & Asymptomatic; normal leaflets mobility \\
\hline 5 & 28 & No & No & - & Asymptomatic; normal leaflets mobility \\
\hline \multicolumn{6}{|c|}{ Patients without satisfactory result } \\
\hline 6 & 0.5 & No & No & - & $\begin{array}{l}\text { Died two weeks after thrombolysis; } \\
\text { poor anticoagulation }\end{array}$ \\
\hline 7 & 51 & Yes (7) & Yes (24) & $\begin{array}{l}\text { Clot; tissue } \\
\text { ingrowth }\end{array}$ & $\begin{array}{l}\text { Asymptomatic; normal function of both } \\
\text { prosthetic valves }\end{array}$ \\
\hline 8 & 30 & Yes (2) & No & - & $\begin{array}{l}\text { Asymptomatic; persistent limitation of } \\
\text { leaflets mobility* }\end{array}$ \\
\hline 9 & 21 & Yes (3) & Yes (19) & Tissue ingrowth & Asymptomatic; normal MVR function \\
\hline 10 & 9 & $\begin{array}{l}\text { No } \\
\text { (primary } \\
\text { failure) }\end{array}$ & Yes (immediately) & Tissue ingrowth & $\begin{array}{l}\text { Asymptomatic, normal MVR function; } \\
\text { defaulted follow-up }\end{array}$ \\
\hline
\end{tabular}

$M V R$, Mitral valve replacement.

*Patient has experienced no symptoms after second thrombolysis and has not been compliant to any further procedure.

competitive method for the treatment of patients with thrombosed left-sided prosthetic valves. Present results confirm that tissue ingrowth is a frequent cause of rethrombosis and suggests that patients with a recurrence of thrombosis should be submitted to a second operation rather than to a second course of thrombolysis.

\section{REFERENCES}

1. Kurzrok S, Singh AK, Most AS, Williams DO. Thrombolytic therapy for prosthetic cardiac valve thrombosis. J Am Coll Cardiol 1987;9:592-8.

2. Silber H, Khan SS, Matloff JM, Chaux A, DeRobertis M,
Gray R. The St. Jude valve: thrombolysis as the first line of therapy for cardiac valve thrombosis. Circulation 1993:87:30-7.

3. Deviri E, Sareli P, Wisenbaugh T, Cronje SL. Obstruction of mechanical heart valve prosthesis: clinical aspects and surgical management. J Am Coll Cardiol 1991;17:646-50.

4. Vitale N, Renzulli A, Cerasuolo F, Caruso A, Festa M, de Luca $\mathrm{L}$, et al. Prosthetic valve obstruction: thrombolysis versus operation. Ann Thorac Surg 1994;57:365-70.

5. Reddy NK, Padmanabhan TNC, Singh S, Kumar DN, Raju PR, Satyanarayana PV, et al. Thrombolysis in left-sided prosthetic valve occlusion: immediate and follow-up results. Ann Thorac Surg 1994;58:462-71. 